\title{
The making of a conservation landscape: the emergence of a conservationist environmental infrastructure along the Kwando River in Namibia's Zambezi region
}

\author{
Michael Bollig and Hauke-Peter Vehrs
}

\section{Introduction}

The giant Kavango-Zambezi (KAZA) Transfrontier Conservation Area constitutes a major part of Southern Africa's vast expanses of protected landscapes. In Namibia's Zambezi region, community-driven conservancies and national parks became part of this giant transborder conservation area, the world's largest inhabited transboundary conservation landscape, in 2011 when KAZA was formally inaugurated. In our contribution, we are interested in the emergence of this conservation landscape. We will focus our analysis on the Kwando River wetlands and adjoining savannahs (see Figure 1). ${ }^{1}$ This landscape features importantly as a migration corridor for large ungulates and as a hub for tourism. The river establishes the boundary between Namibia's Bwabwata National Park and the Kongola constituency for some forty kilometres, and then for almost seventy kilometres the international boundary between Namibia and Botswana. The river meanders for about 100 kilometres through extensive wetlands, establishing many arms, oxbows and islands. Wide treeless and seasonally inundated wetlands and high stands of gallery forest form the core of the wetlands. Beyond the riverine gallery forest, the region is marked by open savannah woodlands. Nowadays, villages are typically located some three to five kilometres away from the wetlands on the Namibian side (whereas the Botswanan side is mostly unpopulated), in a line along the tarred Singalamwe-Kongola-Sangwali road. Extensive agricultural fields are concentrated around the villages. The Kwando River, its wetlands and adjoining savannahs are famous today for their large elephant and hippopotamus populations, their large herds of antelope and gazelle, and their exuberant diversity of bird life. These can be viewed and photographed

\footnotetext{
Michael Bollig is Professor of Social and Cultural Anthropology at the University of Cologne. His interests lie in the environmental anthropology of sub-Saharan Africa. He is the author of Shaping the African Savannah: from capitalist frontier to arid Eden in Namibia (Cambridge University Press, 2020). Email: michael.bollig@uni-koeln.de

Hauke-Peter Vehrs is a postdoctoral researcher at the University of Cologne, currently conducting research in Namibia's Zambezi region with a focus on human-animal relations and environmental history against the background of conservation efforts. Email: hvehrs@uni-koeln.de

${ }^{1}$ Our ethnographic research focused on the Namibian side of the Kwando River. The Botswanan side of the river became depopulated during the course of the twentieth century and is now part of a wildlife management area. We did not conduct research in the archives in Gaborone but profited from three in-depth historical studies of the Ngamiland and Chobe districts (Morton 1996; Gumbo 2010; Bolaane 2013) and other academic publications that looked at the history of the region (Tlou 1985; Potten 1976a; Molefi 2008).
}

(C) The Author(s), 2021. Published by Cambridge University Press. This is an Open Access article, distributed under the terms of the Creative Commons Attribution licence (http://creativecommons. org/licenses/by/4.0/), which permits unrestricted re-use, distribution, and reproduction in any 


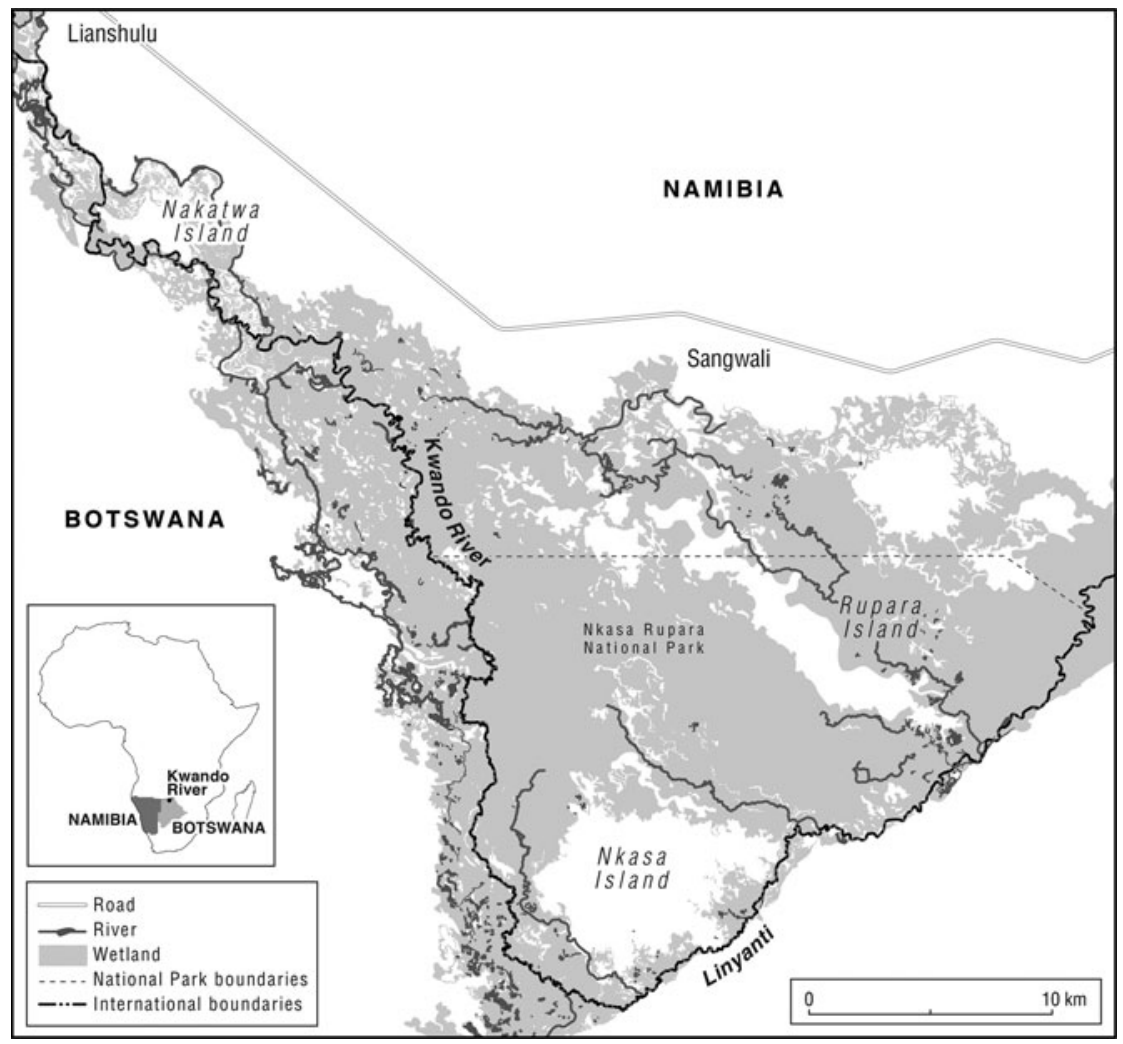

FIGURE 1 The map shows the expansive wetlands along the Kwando River between today's Lianshulu (close to Nakatwa Island) and Rupara Island.

from a good number of high-ranking lodges and campsites. Six community-based conservation areas (conservancies) line the river. Currently, slightly more than 12,000 people inhabit this landscape. ${ }^{2}$

Lenggenhager (2018) has described in detail how the South African colonial regime dominated human-environment relations in the wider Caprivi region (today's Zambezi region administrative unit) and how conservation and militarization became highly entangled dynamics in the 1970s and 1980s. While Lenggenhager (ibid.) adopts an environmental history approach, focusing on the contested governance of natural resources, we try to trace how a specific

\footnotetext{
${ }^{2}$ The Ministry of Environment and Tourism (MET) and the Namibian Association of Community-based Natural Resource Management (CBNRM) Support Organizations (NACSO) estimated that there were 12,173 people living in the six conservancies along the Kwando River in 2017 (MET and NACSO 2020: 80). CBNRM is a concept that stresses the idea of 'participation, empowerment and decentralization' of local communities in nature conservation (Dressler et al. 2010: 5).
} 
environmental infrastructure ${ }^{3}$ has come into being in a process engaging local farmers, traditional authorities and commoners, colonial state officials and conservationists, and, of course, diverse biota, resulting in a conservation landscape. With our contribution, we add to scholarship on dispossession by conservation in colonial times ${ }^{4}$ and in the present. ${ }^{5}$ Whereas the focus of the majority of this scholarship has been on how original inhabitants were dispossessed by different regimes and how dispossessed herders, agriculturalists and foragers coped with enforced relocations, we are mainly concerned with the links between dispossession, resettlement, land-use change and landscape transformation. We argue that the infrastructure of today's conservation landscape is grafted onto a number of past interventions into social-ecological relations. Here, we want to counter the much publicized perception that these conservation areas are pristine landscapes, lands where the precolonial wealth of fauna miraculously continued to survive into the twenty-first century. These landscapes are neo-wildernesses that are meant to serve the needs of global agendas for the maintenance of biodiversity and species survival, national visions of economically productive conservation measures, and local hopes to benefit from conservation through tourism and other conservation-based value chains (as exemplified by Kalvelage et al. 2020).

\section{Methods, theoretical considerations and regional context}

This contribution centres on research in the Namibia National Archives in Windhoek and the analysis of published data from colonial travellers, administrators and subcontracted experts. It is also based on the scrutiny of oral historical accounts from informants living along the Kwando River and anthropological fieldwork in the region since 2018. The historical accounts are more vivid and detailed for the second half of the twentieth century than for earlier decades. Oral accounts recorded with Siyeyi-, Sifwe- and Thimbukushu-speaking informants along the river stress dependency (either on Barotse or on Batawana and later on Mafwe overlords), slave-like servitude, and outright suppression during the precolonial and early colonial era. Whereas for the Barotse and Tawana the activities of leaders and elites have been reported in many publications, ${ }^{6}$ we found oral evidence only sparsely highlighting the political agency of people living along the Kwando River for the early part of the twentieth century. If they are mentioned, it is as victims of oppression and as small-scale agropastoralists, fishermen and foragers using the riverine wetlands intensively. Oral traditions rarely stress individual agency but rather describe the characteristics of

\footnotetext{
${ }^{3}$ Kreike (2013: 22) gives a definition of 'environmental infrastructure'. He defines the concept as comprising 'human and non-human agency to shape or reshape the environment, from mental abstraction to physical execution' and asserts that, "whereas "infrastructure" is commonly held to support human society or enterprise, environmental infrastructure may serve human and nonhuman individuals, communities, activities, forces, and processes'.

${ }^{4}$ See, for example, Dieckmann (2007) on the Namibian Etosha Park and Carruthers (1995) on the Kruger Park.

${ }^{5}$ See Taylor and Beinart (2012) on the Namibian Bwabwata Park and Brockington (2002) on Mkomazi Park in Tanzania.

${ }^{6}$ For the Tawana kingdom, see Tlou (1985) and Morton (1996); for the Barotse, see, for example, Flint (2003) and Phiri (2005).
} 
a particular wetland-oriented lifestyle. Oral evidence then becomes more detailed with accounts of labour migration and the quarrels between chiefs since the 1930s.

Written reports on the region begin with David Livingstone's detailed account of his arduous travels through tsetse-infested country to the Makololo ruler's capital, Linyanti (close to today's Sangwali, right within the research area), and his sojourn and proselytizing efforts there (Livingstone 1870: 95-105). Later reports stress the abundance of wildlife in the area, thereby indirectly downplaying the environmental effects of hunting expeditions (Holub 1880; Selous 1881; Reid 1901). German colonial administration was established in the region in 1909 - and lasted only for some five years. However, there are a number of publications and reports connected to the German colonial annexation. These are less interested in game and hunting than in settlement patterns, native agriculture and the adequacy of the landscape for future colonial efforts in large-scale agriculture and cattle ranching. The tone of these administrative reports is austere and overly detailed. During the short period of German administration, a great number of reports, publications and detailed maps ${ }^{7}$ were produced, presenting information about social-ecological dynamics and preparing for the direct administration of the area (e.g. Seiner 1909a; 1909b; Streitwolf 1911; see also Zeller 2010). While the area was loosely administered by the Bechuanaland Protectorate between 1919 and 1929 (Lenggenhager 2018: 471), the South African administration became established in the early 1930s, organized from Windhoek from 1929 to 1939, and, unlike the rest of Namibia, from Pretoria in subsequent years. Administrative reports become more numerous from the late 1930s onwards. Between the 1960s and 1980s the administration of what was then East Caprivi was fully operational (since 1972, as the administration of a pseudo-independent homeland; ibid.) and produced enormous amounts of material to be archived.

While the Namibian National Archives are well organized and document past regimes of environmental surveillance, concrete data on place-specific socialecological changes are difficult to find. While we heard a lot about the forceful character of relocations in oral testimonies, these relocations were touched upon only in passing in the files of the administration. ${ }^{8}$ Kruger (1984), the South African administrative officer who was responsible for relocations in the 1940s and again in the 1960s, did not mention local resentment in any detail in his unpublished 500-page volume on the history of the region. ${ }^{9}$ Grief and outright anger, so frequently voiced in the interviews we conducted with local seniors, did not make it into the records. The reasons for this are obvious: administrators were interested in emphasizing the voluntary nature of moves and the effectiveness of a small number of administrative staff, stressing their positive contribution to

\footnotetext{
${ }^{7}$ See Map 06043 in the National Archives of Namibia (NAN).

${ }^{8}$ Rarely were large numbers of people involved in such relocations. This is very much in contrast to, for example, the major relocation of 1,200-plus people from the southern Kaokoveld in 1929, which resulted in a number of files describing the circumstances and details of the migration (Bollig 2020).

${ }^{9}$ Kruger left an unpublished volume on the history of the region (NAN A0472). He had worked in the East Caprivi administration between 1940 and 1976 in different functions. While Kruger is explicit about dates and the rough schedule of relocations, he offers little detail regarding exactly how he convinced locals to relocate.
} 
the well-being of the people and the readiness of the local population to react positively to the regulations of the South African administration.

We combined archival research with the recording of oral histories over two months along the Kwando River. ${ }^{10}$ We were met with great willingness on the part of local seniors to talk about place-specific histories. The dominant tone in these interviews was a mixture of nostalgia, grief and frustration. During interviews, it was frequently emphasized that the past life on the banks of the river or on islands was preferable to the lives people were living now in villages along the SingalamweKongola-Sangwali road, some two to five kilometres away from the wetland. ${ }^{11}$ As sketched by Mavhunga (2014: 53) in his essay on an African epistemology of nature, they emotionally described the shift from 'preferred to arbitrary settlements' and emphasized that 'their hearts, spiritualities and material yearnings never left the land' that had become the conservation area. After an analysis of the extensive literature on Ngamiland and Chobe District (Morton 1996; Gumbo 2010; Bolaane 2013), we had anticipated that people with Botswanan origins might highlight the move to Namibia as an escape from servitude and interethnic quarrels, or might emphasize better access to migrant labour recruitment centres on the East Caprivi side of the river. ${ }^{12}$ In contrast, oral testimonies almost uniformly highlighted the forceful character of relocations; they occasionally mentioned improved access to labour recruitment centres, but they never listed escape from servitude and oppression as a prominent motive for relocation.

In what follows we describe how the colonial administration sought to order the landscape by condensing human settlement and emptying parts of the landscape of human habitation. In a second step in exerting control over the landscape, the South African colonial administration (often in conjunction with the Botswanan administration) set out to eliminate sleeping sickness and trypanosomiasis as well as the vicious invader plant Salvinia molesta from the environment by applying vast doses of chemicals. In a final step, the lands of what would become the national parks Nkasa Rupara and Mudumu, as well as a giant state forest, were cleared of human settlement, adding more people to an already densely settled area along the Kwando River.

\section{Land use, domination and environmental restructuring in an unruly landscape}

In the following, we describe the history of the creation of the conservation landscape. We begin with an overview of precolonial and early colonial patterns of adaptation and the political ecology of land use and natural resource exploitation.

\footnotetext{
${ }^{10}$ While a few interviews were conducted in English, the majority were conducted in either Siyeyi, Sifwe or Thimbukushu languages and transcribed and translated later.

${ }^{11}$ This road was constructed in the late 1960s (Kruger 1984: 36).

${ }^{12}$ Morton (1996: 124) reports that Mayeyi living within the Tawana kingdom had few chances to obtain cattle loans through the mafisa system. Mayeyi also resisted enforced villagization by the British administration in the 1950s and 1960s (ibid.: 173) and strongly argued for political emancipation from Tawana overlordship (ibid.: 241). Gumbo (2010: 41) reports on strong Mayeyi resentment against taxation.
} 
We then depict the relocation of villages from the islands and the riparian areas during the course of massive anti-tsetse spraying campaigns from the 1930s to the 1960s. Finally, we delineate the establishment of national parks and protected forests in the 1970s and 1980s and the continued fight against unwanted microbes and invaders.

\section{Settlement and land use in the early twentieth century}

The local population - Sifwe-, Siyeyi-, Khoe- and Thimbukushu-speaking smallscale farmers and fishermen/women, gatherers and hunters - were well adapted to high degrees of environmental variability: seasonal mobility, dispersal of settlements and the exploitation of diverse natural resources were major institutionalized coping strategies. It is important, however, to bear in mind that adaptation took place in a setting characterized by extreme inequality and violent contestations for power and inclusion in a precolonial state. Hard labour, taxation and slave raiding were as significant as inundations, droughts and periodic tsetse fly infestations of the riverine areas.

Seiner, who travelled through the region in 1906, gives a detailed account of settlement patterns in the Kwando Basin around the turn of the twentieth century. He counted forty-one villages and 3,285 inhabitants of Mayeyi, Mafwe and Hambukushu origins along the 'Mashi' (Kwando River) (Seiner 1909b: 102). Seiner's use of the term 'village' is somewhat misleading. On average, a 'village' had about eighty inhabitants, and Frankenberg's highly detailed maps suggest that a village was often merely an extended household consisting of only a few huts (Figure 2).

Homesteads were mobile and shifted seasonally from rainy season to dry season sites. ${ }^{13}$ During the rainy season, homesteads further inland along seasonal water channels (molapos) and pans were used and land was cultivated there. During the long dry season, sites close to the river or on islands were inhabited and planting took place on the floodplains, from which the water receded gradually. Early German maps contain the annotations 'winter village' and 'summer village' to describe this almost transhumant lifestyle. This environmental infrastructure made two harvests feasible per year. Seiner (1909b: 33) reports that, due to the lack of livestock and the consequent lack of fertilizer, homesteads had to shift after a few years in order to make new fields.

Between the 1890s and the 1910s, only a few cattle were herded along the Kwando Valley. Apparently, the regional cattle population was completely wiped out during the period of the great rinderpest in 1898 (Seiner 1909b: 102). Seiner reported in 1906 that the Mayeyi did not have any cattle and the Mafwe had only a few (ibid.). However, the Barotse elite sent large numbers of cattle across the Zambezi each dry season and had them herded in the wetlands of the Linyanti and Kwando in the first decade of the twentieth century. Streitwolf (1911: 73) reported that the Barotse took back some 20,000 cattle across the Zambezi into south-western Northern Rhodesia (now Zambia), fearing that the German administration could close the boundary more permanently in 1909 .

\footnotetext{
${ }^{13}$ Morton (1996: 55) describes the productivity of Mayeyi floodplain agriculture and Mayeyi expertise in fishing in the Okavango Delta wetlands. The wetland subsistence system he reports on is highly resilient to drought and other perturbations.
} 


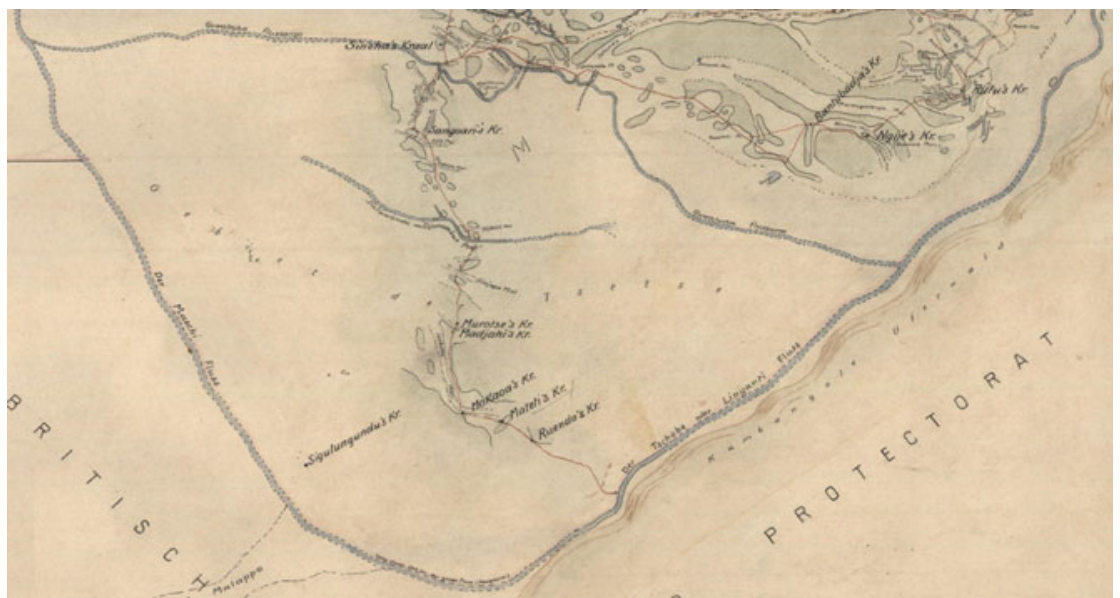

FIGURE 2 Frankenberg's map of the south-western parts of the Caprivi (Map 06043, National Archives of Namibia). He depicts some five homesteads south of 'Sangoari's Kraal', dispersed along a water channel. Frankenberg produced a number of high-resolution maps covering the entire region along the Kwando River. The maps have the obvious aim of capturing the exact position of every homestead in the region. They also attempt to give an exact account of watercourses in the inundation plains along the major rivers.

Beyond direct resource exploitation through large cattle herds, the Barotse dynasty installed chiefs and allotted 'villages' to them, which the chiefs treated as a kind of fiefdom. They were entitled to call upon the labour of their subjects and to force local residents to pay taxes in the form of skins (Reid 1901: 580). The Tawana also arranged for large numbers of cattle to be herded along the Kwando by herdsmen. Morton reports that some Bayeyi herded cattle for Tawana leader Sekgoma in the wetlands in the 1890s (1996: 88).

The precolonial social-ecological system was marked by the intensive exploitation of natural resources and people on the fringes of two precolonial states linked via numerous trade relations to the Cape- and Angola-based trading empires. Exploitation took place in several ways: for example, people endured hard labour for chiefs installed by the Barotse king and had to pay tribute to overlords on both sides of the river (see Morton 1996: 106 for Ngamiland). Some oral accounts also stressed that occasionally slaves were directly taken in the region and brought to Barotse royal homesteads in southern Zambia.

\section{Hunting}

Many reports from the late 1880 s to the early twentieth century mention the abundance of game in the area and the defaunation brought about by white commercial hunters at the turn of the century. The well-watered lands of the ZambeziKwando-Chobe triangle were a hunter's paradise for three decades. Lozi rulers claimed primary hunting rights there and regarded parts of the wetlands as a hunting reserve; hunters of European descent had to ask for their permission to 
hunt in their area (and likewise with Tawana rulers on the other side of the Kwando/Chobe Rivers). By around 1900, the activities of commercial hunters had been severely curtailed in British Bechuanaland and the two Rhodesias, but not in the Caprivi Strip, which was still not administered at the time. Profits from commercial hunting in the Caprivi were remarkable: Fisch (1996: 45) estimates that about fifty Boer hunters were active in the region in the first decade of the twentieth century and made about 4,000 Marks profit per annum. ${ }^{14}$ Seiner (1909a) reports on unemployed British railway workers who tried to bridge the gaps between their contracts by hunting in the region. He also describes two British officers who roamed the region with fifty-two carriers, of whom eighteen were carrying game trophies. In the first decade of the twentieth century, two traders and commercial hunters settled for some years on the Kwando River: the British trader Todd lived in Choi from 1904 (though on the western Bechuanaland Protectorate side of the river) and hunted for a trading company based in Livingstone. According to Fisch's extensive analysis of archival sources (1996: 48), he shot about 400 hippos in the region, whose skins were made into straps and whips, and employed about thirty locals in his hunting business. Defaunation must have had an enormous effect on the local environmental infrastructure. Shaping of the environment by elephants, the most impactful landscape architects in this social-ecological system, as well as by other large ungulates was eliminated or greatly reduced. In addition, the severe reduction of hippopotamus numbers would have had enormous effects on the ecology of riverbanks. ${ }^{15}$

The local population apparently did not take part in the tropical commodities bonanza to any significant degree. Several reports mention that locals owned hardly any guns. Streitwolf (1911: 227) counted among the Masubia, Mayeyi and Mafwe only seven Hinterlader (breech-loading) and twenty-one outdated Vorderlader (muzzle-loading) guns. Only the Hambukushu were somewhat better armed: they owned some forty Hinterlader guns, profiting from better trade relations with Portuguese traders. In comparison, in 1917 and 1919, when the population of the Kaokoveld in north-western Namibia was disarmed by the South African army, many more modern arms were confiscated (Bollig 2020: 110). People in the Kaokoveld had also taken a more active part in the ivory bonanza, trading with Portuguese traders either directly or via Oshivambo-speaking overlords on the western Cuvelai floodplains. The royalty of the Ovambo, Kwangali, Lozi and Tawana kingdoms and chiefdoms held monopolies over the ivory trade and controlled the hunting of elephants vigorously. Along the Kwando River, though, locals acted mainly as porters for the many hunting caravans. Neither in oral accounts nor in written testimonies is there any account of them directly engaging in the ivory trade.

\footnotetext{
${ }^{14}$ The German Bundesbank states the purchasing power equivalents of historical amounts in German currencies with a factor of 7.0 for the year 1900, resulting in 28,000 marks (Bundesbank 2020). It is also important to consider the purchasing power equivalent of the German currency at that time. The Bundesbank (2019) compares the purchasing power in different years. For example, a kilogram of rye bread cost 0.26 marks in 1982 (compared with $€ 3.05$ in 2019), a kilogram of potatoes 0.07 marks (2019: €1.56), one litre of milk 0.17 marks (2019: $€ 0.89$ ), or a kilogram of butter 1.98 marks (2019: €6.89).

${ }^{15}$ Spinage (2012: 626) documents the effects of severe reductions of hippopotami on vegetation in the Queen Elizabeth National Park of Uganda in the 1950s and 1960s.
} 
While the local population was not actively engaged in commercial hunting, subsistence hunting made an important contribution to local livelihoods (and continues to do so today; see Lubilo and Hebinck 2019). Large animals such as hippos and buffalo were hunted as much as antelopes and other wildlife - albeit mainly by traditional means. Both Mayeyi and Mafwe material culture displays a wealth of different traps, and gathering seems to have been of greater significance.

\section{Relocations during the first half of the twentieth century}

From the late 1920s, South African colonial authorities started to have an impact on this social-ecological system through the resettlement of homesteads. The general direction of these moves is clear: the western banks of the Kwando and Linyanti (the Bechuanaland Protectorate side) and the islands in the inundation areas were cleared of population, as was the Western Caprivi Strip. Homesteads were resettled along the eastern banks of the Kwando. While some moves were enforced (according to oral traditions), others resulted from continuous negotiations between the administration and local inhabitants. Some moves were apparently voluntary: people from the Western Caprivi and the Bechuanaland banks of the Kwando, for example, hoped to get better access to labour recruitment when resettling on the eastern banks of the Kwando, as some informants claimed. While the major labour recruitment organization, WNLA (Witwatersrand Native Labour Association, locally often dubbed WENELA), started to recruit workers for the Witwatersrand mines in northern Bechuanaland Protectorate through offices in Maun and Shakawe in the mid-1930s, recruitment was started in the East Caprivi in the 1940s with a recruitment office in Katima Mulilo (Kangumu 2011). ${ }^{16}$

Let us take an area-specific look at these relocations before digging deeper into their rationale. Lenggenhager (2018: 55) reports that in 1938 colonial authorities decided to clear the panhandle part of the Caprivi of livestock and people in an effort to control the spread of livestock diseases. Only Hambukushu agropastoralists were forced out of the area, while Khoe speakers, most of them without livestock and thought of as aboriginal hunters and gatherers, were allowed to stay. ${ }^{17}$ When interviewing senior people along the Kwando River, recollections of these moves were frequent. The local headman, Induna Jameson Makeswa from Maparanga, ${ }^{18}$ described how people were relocated from the islands and the riverbanks:

Originally, we are from Western Caprivi, Mbire, Nambwa, Ruru, Rwanga. These are places on islands in the Kwando River. It was under Kruger that we were moved from these islands. We were forced to do so. It was Mafwe and Hambukushu people being moved. We were under Mamili. [Continues to describe the food on which they subsisted on the islands.] We were living with Kwengu in these sites. Wherever we were, there were

\footnotetext{
${ }^{16}$ Gumbo (2010: 39) estimates that, by 1943, about 11,550 labourers from Ngamiland and Chobe District had been recruited for labour in South Africa by WNLA. He asserts that colonial taxation was a major motivation for labour migration.

${ }^{17}$ Interview with Induna Freddy Kadimba Sinyemba from Namushasha, 11 September 2018.

${ }^{18}$ Kruger (1984: 421) mentions a person called 'Maplanka [who] had been removed at the instance of the Bechuanaland Administration (1921-1929)'. Apparently, the village is named after this person, who was resettled from the Botswana side of the river.
} 
also Bushmen. Of course, we were also marrying each other. I was not born there but here [in Choi]; but my father was born on the island. I know all the places there and I can travel through the night there. We moved over a number of years. Later, other Mbukushu from Mambombondjira were moved from the islands to Choi. They were moved because of tsetse; when we were still at the island there was nobody at Choi, it was bush; when coming from the island we first stayed at the bank of the river; the place is called Kuwunyana; floods forced us to move away from Kuwunyana. When the spraying took place [i.e. in the late 1960s] I was already an adult person; after the tsetse was cleared it became a park; the government does not allow us to go back to the land of our ancestors. ${ }^{19}$

In his recollections, Kruger, the administrative officer responsible for these relocations in the 1940s, describes how he could operate freely and in cooperation with Bechuanaland and later Botswana administrative staff along the western and southern banks of the river. Kruger repeatedly moved across the river himself to talk to people and to convince them to shift to the South African-mandated side. From the 1930s onwards, the Bechuanaland administration developed the lands south of the Chobe River and west of the Kwando River as conservation areas, and communities of mobile foragers and more sedentary riverbank-dwelling agro-pastoralists were perceived as a hindrance. ${ }^{20}$ The activities of Kruger were probably welcomed by the colonial administration.

Immigration from the western banks of the river also took place in the Lizauli area at the northern edge of today's Mudumu National Park. Kruger (1984: 268) reports that, in 1941, 'no less than six villages totalling 332 souls and bringing their livestock moved from Betchuanaland'. Moves between the islands of Nkasa and Rupara, in the bend of the Linyanti River, and Sangwali went back and forth for at least two or three decades. Frequent movements between both islands and Sangwali attest to the difficulties the administration faced in controlling mobility. Kruger (ibid.: 247) mentions that people living on the islands of Rupara and Nkasa had already been resettled for the first time in the early or mid-1930s: that is, before he took up his office in the Caprivi. Both islands had been diagnosed as heavily infested by tsetse at that time and relocations were framed as a rescue operation. Some households returned to Nkasa and Rupara islands during a drought in the early 1940s, and one informant claimed that a larger number of people had gone back to the two islands by $1948 .{ }^{21}$ In 1968 they were relocated once again in a move to control the spread of tsetse. ${ }^{22} \mathrm{~A}$ hospital and school being built in Sangwali motivated these final moves away from the islands. The negotiation of the moves in the late 1960s was orchestrated between the colonial administration and the Mafwe tribal leadership without the consultation of local Mayeyi residents, as a number of informants bitterly complained. Not only were the Siyeyi-speaking residents of the islands risking sleeping sickness

\footnotetext{
${ }^{19}$ Interview with Induna Jameson Makeswa from Maparanga, 11 September 2018.

${ }^{20}$ Chobe Game Reserve was gazetted in 1960 and became a national park in 1967 (Spinage 2012: 804), while the Batawana tribal leadership established the Moremi Wildlife Reserve in 1964 (Potten 1976b; Bolaane 2013). While these formalizations of conservation status occurred only in the 1960s, pro-conservation policies had already been adopted in the 1930s (Vandewalle and Alexander 2014: 95).

${ }^{21}$ Interview with Elia Musamai Samachaze, 10 September 2018.

${ }^{22}$ Interview with Lennard Shitaa Limbo and Induna Mbambazi, 8 September 2018.
} 
but they were ostensibly also trespassing into the hunting territory of the Mafwe traditional authority. Nkasa and Rupara were declared the hunting grounds of the Mafwe chief by the administration - a neotraditional invention benefiting the Mafwe tribal leadership, which had become central to the administration of the East Caprivi homeland. Such hunting territories of the Mafwe chief are not mentioned in earlier literature; only a royal hunting territory of the Barotse king along the banks of the Chobe River in precolonial times is reported (Streitwolf 1911: 228-9; see also Bolaane 2013: 28).

\section{The environmental impact of these relocations}

One obvious consequence of these relocations was that the western banks of the Kwando/Chobe were emptied of settlements, making way for a new kind of environmental infrastructure. From the 1960s onwards the elephant population increased rapidly along the Botswanan banks of the Chobe (Skarpe et al. 2014b). On the basis of an extensive literature review, Spinage (2012: 798, 802) describes how elephant numbers went up from a few herds in the 1940s to around 5,700 animals in the early 1970 s, and then to between 65,000 and 94,000 in the 1990s in northern Botswana. This had grave consequences for the vegetation. Skarpe described sizeable changes in the flora of the Chobe floodplains as a consequence of herbivore grazing (Skarpe et al. 2014a). The grass species Cynodon dactylon and Vetiveria nigritana became dominant, since they were tolerant of the intensive grazing of large herds of herbivores and able to take up nitrogen directly from urea deposited in animal urine (ibid.: 51). The forb Heliotropium ovalifolium became abundant on the floodplain due to its production of a potent alkaloid that is avoided by herbivores. We surmise that similar processes took place on the western (i.e. Bechuanaland) side of the Kwando under very similar ecological circumstances, where the human population rapidly decreased from the 1940s onwards and game populations increased.

Social-ecological dynamics on the Namibian side pointed in the opposite direction. A number of new villages came into existence with homesteads amalgamating into villages. Many were located along a road that was developed in the 1960s and ran parallel to the Kwando River. ${ }^{23}$ Comparing land-use patterns in the early 1940s, the 1970s and the 1990s, Mendelsohn et al. (2002: 29) diagnosed an increase in agriculturally used land and a decrease in forested land. This densification of settlement resulted in more frequent burning of lands and a degradation of the vegetation. The intensification of land use was observable all along the eastern side of the river, as maps displayed in Mendelsohn et al. (ibid.: 29) show, for example, for the Kongola and the Chinchimane area. We argue that a good deal of this intensification and expansion of land use was connected to relocations ${ }^{24}$ and linked to the introduction and diffusion of the plough in the region since the 1950s. ${ }^{25}$

\footnotetext{
${ }^{23}$ Morton (1996: 166) reports that villagization was also a salient characteristic of land-use changes in north-western Botswana in the 1940s and that it was much resented by Mayeyi.

${ }^{24}$ Mendelsohn et al. (2002: 29) work on four areas area of cultivation and analyse remote sensing data for the years 1943, 1972 and 1996; they find evidence for a rapid expansion of cultivated areas in the 1950s and 1960s.

${ }^{25}$ In a number of interviews with former labour migrants they described that in the 1950s and 1960s they often bought ploughs with their wages and that ploughs replaced digging sticks within
} 
Game populations decreased rapidly on the Caprivi side of the Kwando in the 1960s and 1970s. Lenggenhager has shown that decreases in wildlife numbers resulted directly from militarization and the stationing of thousands of South African soldiers in the region (2018: 131-5). The intense collaboration between the army and the administration paved the way for poaching at commercial levels and as a leisure activity. Militarization and a push for agricultural development went hand in hand and became salient forces of land-use transformations after the East Caprivi's pseudo independence in $1972 .{ }^{26}$ South African planners clearly envisioned that part of the region as having great agricultural potential. In 1963, the Odendaal Report - the masterplan for South Africa's Bantustan policy for Namibian homelands commissioned by the South African government (Wallace and Kinahan 2013: 261) - argued that a diversified rural economy based on commercial fisheries, sustainable forestry, export-oriented agriculture and commercial ranching should be the blueprint for future development of the East Caprivi. ${ }^{27}$ Unlike previous visions for the development of the region, conservation did not feature significantly in the Odendaal planning for the East Caprivi.

A key element of the agricultural intensification strategy was the elimination of the tsetse fly (Glossina morsitans), which brought bovine trypanosomiasis and human sleeping sickness. Due to its sizeable impact on cattle herds, the disease regime led to a scarcity of draught oxen and to suboptimal agricultural practices.

\section{The anti-tsetse campaigns of the 1960s and agricultural improvement}

Trypanosomiasis, including the human form, sleeping sickness (both transmitted by the tsetse fly), was a major factor delimiting the agricultural development of the region. ${ }^{28}$ Already in the mid-1850s David Livingstone had observed serious tsetse infestation in the wetlands along the Linyanti and the Kwando (Livingstone 1870: 95-7). Reid, who hunted along the banks of the Kwando and Chobe in the late 1890 s, observed that both buffaloes and tsetse flies had become rare by the end of the decade, but that the fly was still preponderant in the wetlands on the southern banks of the Chobe. ${ }^{29}$ The decline of tsetse flies was apparently connected to the demise of wildlife populations and cattle herds, both acting as hosts for trypanosomes, during the years of the rinderpest. ${ }^{30}$ Reinfestation of the Chobe wetlands

a decade or two. Sledges, which are deemed to be a traditional means of transport in the region, were also introduced then, using the spanning technology of ploughing.

${ }^{26}$ Kangumu (2011) and Lenggenhager (2018) describe how the East Caprivi gained homeland status in 1972, creating a number of pseudo-independent political institutions. Lenggenhager in particular shows how, in the late 1970s and 1980s, the homeland administration and the South African army cooperated on a number of projects pertaining to natural resource management.

${ }^{27}$ NAN Odendaal Commission (OCO) Secretary of the South West Africa Commission 1963 (Odendaal Commission); microfilm, AMR 0022-0029, p. 293; accessioned as A.0794. The original is in the National Archives of South Africa, Pretoria.

${ }^{28}$ Knight (1971: 25) highlights the complex ecological interrelationships between the disease pathogen, the tsetse vector, and the behavioural patterns of humans, wildlife and domestic animals.

${ }^{29}$ Reid (1901: 584) reports on his 1899 expedition: 'With the decrease in the larger game, the tsetse fly has practically vanished, and while I saw millions in 1895, in 1899 we saw only some half-dozen.'

${ }^{30}$ For a similar account on the relation between rinderpest and the decline of trypanosomiasis in the Zambian Luangwa Valley, see Munang'andu et al. (2012). 
by tsetse started in the 1940s and tsetse had again become widespread in the late 1950s, causing severe losses in cattle herds. In north-western Botswana, the British colonial administration had rolled out a massive tsetse-eradication programme in the 1940s after tsetse infestation had become prevalent in the 1930s in the Okavango Delta. There, the Tsetse Fly Control programme (TFC) was founded in 1943 (Morton 1996: 170, 179, 181, 216), and on the eve of independence the programme was the largest employer in Ngamiland, with over 1,000 locals engaged in tsetse-eradication activities (see also Gumbo 2010: 52). Massive spraying with DDT had already been implemented there in the 1950s. South African activities followed the Bechuanaland/Botswana strategy of tsetse eradication, but did so at a low, cost-saving level.

Despite all the control measures, the 20,000 head of cattle in the Kachikau Enclave along the Botswanan Chobe riverfront collapsed to 'virtually nil' between 1947 and 1952 (Spinage 2012: 804). By the mid-1960s, cattle herds on the East Caprivi side of the Kwando/Chobe had been seriously diminished and cases of human sleeping sickness were frequent. ${ }^{31}$ By the early 1960s the Sangwali and Lianshulu region had hardly any cattle at all. Large-scale spraying of the Kwando Basin with targeted spraying of Glossina breeding grounds, and later with insecticide spraying from low-flying planes, was seen as the only appropriate method to combat the vicious fly. ${ }^{32}$ Spraying was first conducted with the chemical dieldrin and then with its successor endosulphan, both substances later prohibited worldwide because of their devastating ecological and health consequences (Kurugundla et al. 2012).

Kruger (1984: 307) describes a fact-finding mission on the tsetse issue in 1966, when he marched along the western banks of the Kwando (that is, through Botswanan territory) with other officers and local traditional authorities in order to find out how serious the infestation by tsetse had become. In the colonial papers there is little (or no) speculation as to why the tsetse fly population expanded once again. A recent paper by Munang'andu et al. (2012) on the dynamics of trypanosomiasis in the Zambian Luangwa Valley suggests that the increase in wildlife due to conservation supplied the disease-carrying fly Glossina with the necessary hosts to multiply rapidly and to expand its reach. In fact, increasing wildlife numbers in the adjoining parts of Botswana/ Bechuanaland, ${ }^{33}$ and also increasing cattle numbers in the western parts of the Eastern Caprivi in the 1940s, may have had the same effect in the Kwando Basin.

\footnotetext{
${ }^{31}$ In Bechuanaland/Botswana, the pressure was also immense: in Ngamiland, the number of cattle had declined from approximately 190,000 in 1932 to 114,000 in 1938, unleashing massive administrative activities (Morton 1996: 166). In the 1970s, hardly any cattle were to be found in Chobe District (Gumbo 2010: 68) while cattle numbers had more than recovered in Ngamiland and had risen to 355,000 in 1981 (ibid.: 66) due to effective anti-tsetse measures.

${ }^{32}$ Potten (1976a: 69) reports that, in Botswana, the eradication of wildlife as a carrier of trypanosomes was also practised. Employed by the TFC, some fifty local hunters were working full time and killing more than 4,000 head of wildlife in a year. Potten further reports that, between 1942 and 1964, some 60,638 head of wildlife were killed, mainly warthog, buffalo and kudu. The major centres of these wildlife eradication campaigns were around Maun.

${ }^{33}$ In an interview on 10 September 2018, Induna Elia Musamai of Samachaze claimed that 'tsetse came here through wild animals from Botswana'; Musamai, who was born in 1944, clearly stated that when he was a child there were no tsetse, that he was a young man when tsetse came, and that they killed many cattle.
} 
The South African colonial government and the government of Botswana embarked on a substantial joint anti-tsetse campaign from 1966 to 1968 and again in the early 1980s. Aerial spraying with dieldrin was successfully implemented and by the late 1960s the entire area - apart from a tsetse pocket at Lianshulu had apparently become tsetse-free. Kruger, the administrative officer who was preparing the campaign on the ground (Kruger 1984: 422), suspected that the application of high doses of the chemical was not advisable, but insisted that chemical warfare against the fly was the only solution to provide the basis for agricultural intensification. ${ }^{34}$ The use of dieldrin started in 1966 and for two to three years it was sprayed by extension staff on both sides of the boundary; it was disparagingly named tsetse vlieg bantoe (tsetse fly Bantu) ${ }^{35}$ in some communications within South African colonial offices. ${ }^{36}$ Interviews with two sprayers ascertained that they were warned of the poisonous effects of the insecticide but that they were given hardly any protective clothing (see Figure 3). ${ }^{37}$

Obviously, the campaigns of the late 1960s had not been as successful as originally claimed. In 1972, for example, the director of veterinary services in Katima Mulilo ordered another 10,000 litres of Dieldrex for some 9,000 rand. ${ }^{38}$ Apparently Dieldrex and then endosulphan were used throughout the 1970s. In 1980, a new major transnational campaign of spraying with endosulphan was endorsed. The Botswanan government proposed that its aircraft would fly five cycles across the Chobe into the Caprivi (see Figure 4). The note also stated that 'endosulphan used at $12 \mathrm{mg}$ per hectare is harmless to the environment and to the human population and livestock'. ${ }^{39}$ This assumption was not corroborated by scientific findings, and by the late 1960s (at the latest) the serious effects of both organochlorides, dieldrin and endosulphan, were obvious.

Tests in northern Botswana showed that many animals other than insects were lethally affected by dieldrin spraying: birds, fish, mammals and reptiles. Endosulphan is less toxic than dieldrin, but even with the low dosage of 10 grams per hectare, deleterious effects on fish (especially tilapia) were observed in shallow water. Also fish-eating birds (including the kingfisher, Ceryle rudis) were affected (Kurugundla et al. 2012). The two former sprayers interviewed had vivid memories of the toxic effects of the chemicals: they claimed that their eyes would burn intensely and that rashes on the skin were common. They remembered sprayers often being rushed to Katima Mulilo hospital after inhaling too

\footnotetext{
${ }^{34}$ Russell (2001) points to the close relation between research on insecticides and chemical warfare.

${ }^{35}$ See NAN CAF 51.6. 20/3, 'Dr J. Erasmus to Staatsveerarts, Pretoria, Problems ondervid te Caprivi Zipfel deur Mnr. J. H. Smit, Veeinspekteur', which reports on the payment of '26 drukgang bantoes, 10 tsetsevlieg bantoes en 12 "cattle guards".

${ }^{36}$ Potten (1976a: 70) asserts that, from 1967 to 1969 , a large operation took place in northern Botswana using dieldrin distributed by teams with knapsack spraying equipment.

${ }^{37}$ Interview with Elias Muzamei and Nelson Munyandi, 24 March 2019.

${ }^{38}$ NAN CAF 51.6, 'Kluge, Directeur van Veeartsenerydies to Bantoe Administrasie en Ontwikkeling', 29 February 1972 on the costs for 'tsetsevlieg bespruitings veldtog'. See also NAN CAF 51.6, 'Dept. of Bantu Administration to Bantoesakekommissaris Katima Mulilo', 8 March 1972, in which further money was promised for the Dieldrex supply for direct spraying. This letter also spoke of a 'veldog' (crusade) against the disease.

${ }^{39}$ NAN CAF 2-1, 'Memorandum of the Chairman of the Executive Council. Administration for the Caprivians. Katima Mulilo’, 24 September 1980.
} 


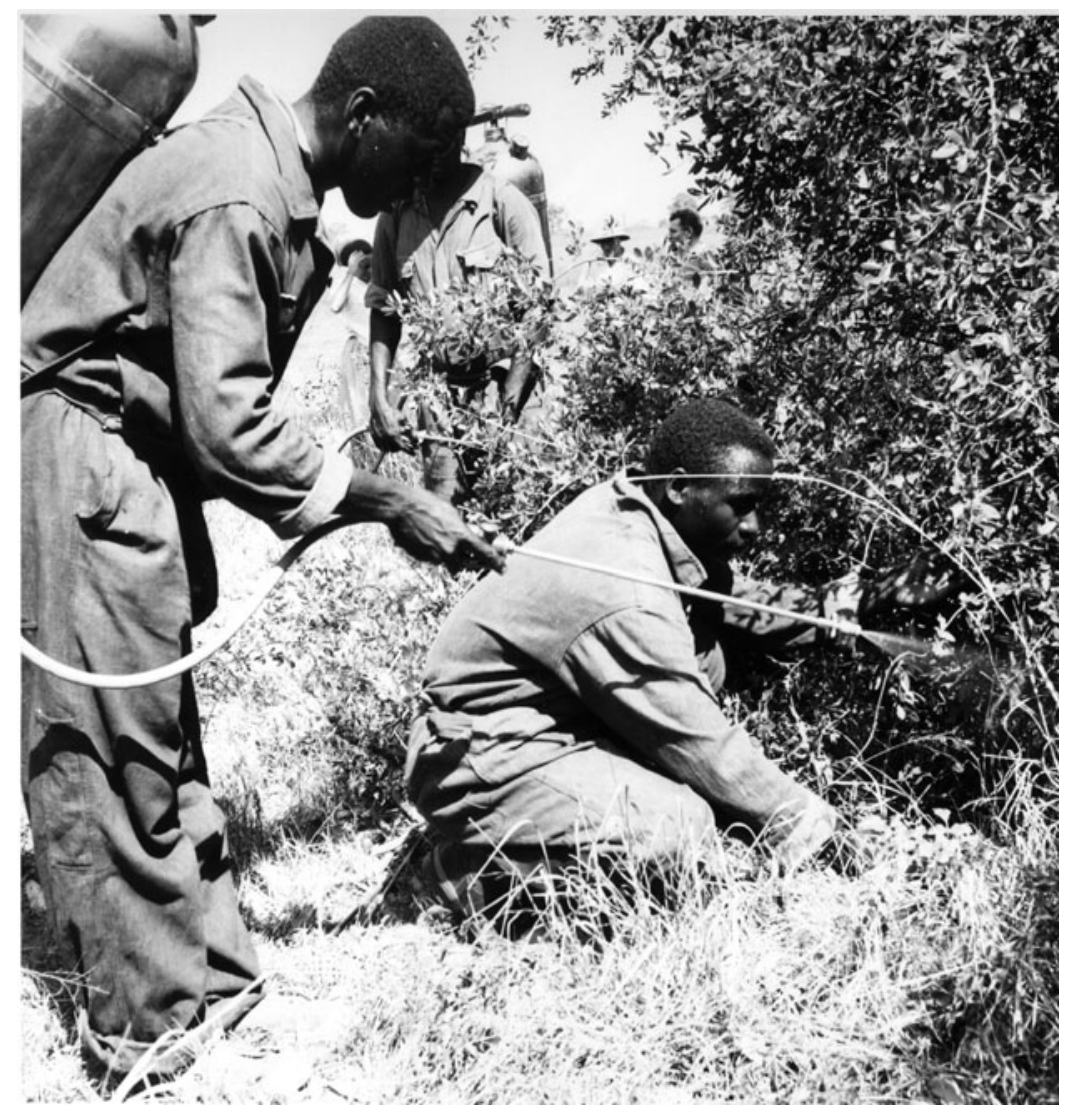

FIGURE 3 Spraying against tsetse fly in the Caprivi Strip, c.1965. Archival records testify to the further use of dieldrin-derived products in the early 1970s. Source: NAN Photo Collection 05504.

much of the insecticide. They also clearly recalled the toxic effect it had on fish. One informant remembered cleaning his spraying instruments in the river and seeing dozens of dead fish soon afterwards.

The anti-tsetse campaigns resulted in further relocations of people from the riverine oasis. While the official attitude towards spraying was that the insecticide was not harmful to humans, officers on the ground acknowledged its effects and urged those who remained settled in riverine lands where the fly was still common to move on. In large parts, though, the riverine environment had already been emptied of settlement before the mid-1960s. While the spraying did not succeed in eliminating Glossina morsitans, it delimited the range of the fly significantly. Cattle numbers increased rapidly again from the 1970s. The fact that the riverine environment is largely tsetse-free nowadays may have also contributed to the establishment of a tourist industry along the Kwando since the 1980s.

Lenggenhager (2018: 112-16) details a second instance of biochemical warfare against unruly nature. From the early 1960s, the aquatic invader fern Salvinia 


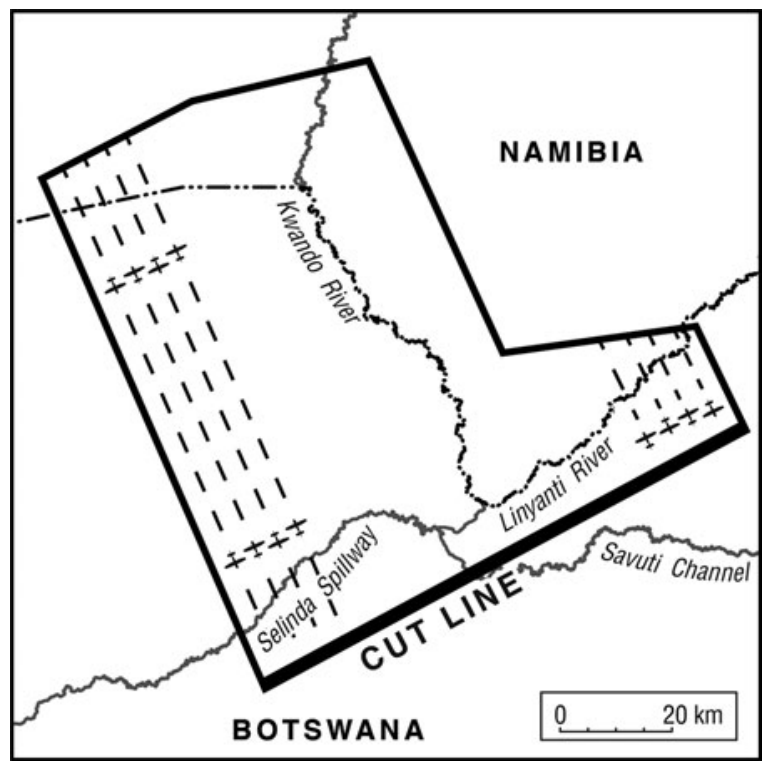

FIGURE 4 Aircraft-based anti-tsetse campaigns in the early 1980s. The map shows the Kwando River and sketches the cross-boundary flight schedule.

Source: NAN CAF 2-1, 'Memo by the Chairman of the Executive Council for the Administration for Caprivians on "Proposed eradication of the tsetse fly in the Kavango Delta”, 24 September 1980.

molesta, originating in the greatly transformed Lake Kariba ecosystem (the hydropower dam there was finalized in 1959), spread rapidly and with grave impact into the wetlands of north-eastern Namibia. ${ }^{40}$ Officials feared major threats to the fishing economy and saw the habitat of a number of wetland-dwelling species imperilled. Salvinia molesta threatened the existence of the wetland ecology and reduced its attractiveness for tourists. Military officers also feared that insurgents could enter the Caprivi more easily, with a number of waterways cloaked by the explosive expansion of the weed. Military personnel, ecologists and administrative officers collaborated to eliminate the invasive plant. The South African air force supplied imagery to trace the expansion of the weed. As in the fight against Glossina morsitans, South African officials collaborated closely with those in Bechuanaland/Botswana. ${ }^{41}$ After testing physical weeding and pesticide spraying, the spread of Salvinia molesta was brought under effective control only in the mid-1980s, when a biological control was implemented: the introduction of the

\footnotetext{
${ }^{40}$ NAN CAF 6/19/15/1, 'D. S. Mitchell, Dept. of Botany, University College of Rhodesia: a survey of Salvinia auriculata in the Chobe River system, March 1967'. This outlines the spread in desperate words, highlighting the exponential growth of the invader weed.

${ }^{41}$ NAN CAF 6/19/15/1, 'Memorandum on the Joint South Africa-Botswana Salvinia molesta (Kariba weed) control and monitoring project in Eastern Caprivi Region and Northern Botswana', 7 July 1977.
} 
weevil Cyrtobagous salviniae (like Salvinia itself, of Latin American origin) caused the salvinia mats to sink and gradually decompose, and the threat of Salvinia molesta to the wetlands was eliminated (Schlettwein and Giliomee 1990; Schlettwein and Bethune 1992).

With control over flora and fauna, nature was clearly divided into unwanted aliens (such as Salvinia molesta) or disease-causing microbes (as carried by Glossina morsitans) and desirable wildlife. Capital, technology, science and personnel were engaged to produce an environmental infrastructure without unwanted ingredients. In a final step, entire landscapes, now including those at a distance from the Kwando River, were cleared of human population to provide more space for wildlife conservation and forest development.

\section{Moves from Mudumu and the state forest}

The establishment of the huge state forest north of the Kongola-Katima road was another major environmental infrastructure project carried out in the early 1970s. In the late 1960s Breitenbach, a renowned South African forest expert, was brought to the Caprivi to develop a forestry plan for the area, which would simultaneously provide for forest conservation and sustainable economic utilization. Breitenbach (1968) left a sizeable report in which he planned forestry for a 120year period. He proposed six forest reserves covering approximately 560,000 acres (c.2,300 square kilometres), around 19 per cent of the Eastern Caprivi's total area. Forty per cent of the forests were earmarked for wood production and 60 per cent were allocated for conservation purposes. Breitenbach planned all forest reserves to be established between 1971 and 1977. In the end, only the largest of the six forest reserves came into being; it was established north of the Kongola-Katima highway in the mid-1970s and is still in existence. Breitenbach (ibid.: 77) identified only 'a few scattered areas of cultivated land', which - according to him - made up only 1 per cent of the total cultivated land of the East Caprivi homeland, and 'can therefore be abandoned without difficulty - their inhabitants, if any, must be resettled outside the reserve'.

A last set of relocations that shaped the landscape profoundly took place in the late 1970s and early 1980s. The Eastern Caprivi Development Plan of 1983 (van der Vegte et al. 1983) considered a number of game reserves, the two largest being Nkasa Rupara and Mudumu. In contrast to the earlier Odendaal Plan, both conservation targets and a reorientation of the economy towards game production were considered. Van der Vegte et al. (ibid.: 154) argued for park status for substantial amounts of land in the Kwando Valley, claiming that it is probable that game yields a higher amount of meat per hectare than do cattle. The Mudumu Reserve could provide the initial research to verify this, and, if so, could form the kernel of a game-farming enterprise adjoining the reserve. ${ }^{42}$ Already in 1976 van der Waal had published a map setting out the location of what was to become Mudumu National Park and Nkasa Rupara National Park, the first given as

\footnotetext{
${ }^{42}$ The reasoning behind Nkasa Rupara Reserve differed from this economic argument in the strategic land-use plan of van der Vegte et al. (1983). The plan argues that Nkasa Rupara was a traditional hunting ground of the Mafwe chief, and 'unless some control measures are taken to regulate hunting there will be no game left for the Chief and his hunters' (ibid:: 154f.).
} 
Lianshulu Hunting Reserve and the second as Lupala Hunting Reserve. ${ }^{43}$ It also mapped the state forest north of the Kongola-Katima road. A first look at this map prompts the question of where agricultural development would have taken place if van der Waal's plan had been carried out. But van der Waal was apparently not thinking of national parks but of hunting reserves, in which human settlement was still permitted. The planning document not only laid down boundaries but also stipulated that local people needed to profit from such conservation efforts. The document also considered that further limited use of the conservation area should be facilitated.

While Mamili (now Nkasa Rupara) National Park was already free of settlements at that time - final relocations from Nkasa and Rupara islands had already taken place in the 1960s and 1970s - what was to become Mudumu National Park still contained one major village (Lianshulu) close to the Kwando River. Lenggenhager (2018: 165-7) gives a detailed account of the resettlement process on the basis of interviews he conducted in the region and with former representatives of the Eastern Caprivi authority, who were directly negotiating the relocations with the traditional authorities. While the traditional authorities sided with the conservationists in the administration, local Caprivian politicians (many of them critical of the pro-South African stand of traditional authorities) opted for renegotiations and a shift of the park further inland away from human settlements (but also away from the wetlands of the Kwando River). On 15 June 1980, people from Lianshulu were summarily forced to leave the area in what local people called a 'night attack'; they were 'dumped' a few kilometres south of the park. People today are still angry about the vast and unsubstantiated promises that were made in order to convince them to move. Informants alleged that several hundred people of Mayeyi origin were forcibly relocated. Promises to supply water, housing and health infrastructure were not kept. ${ }^{44}$ The area was formally inaugurated as a national park just days away from Namibia's independence in 1990 in an obvious effort to prevent the new Namibian government from taking a second look at these relocations (Lenggenhager 2018: 158-61).

The relocation helped create an environmental infrastructure that was conducive to the mobility of large herbivores. A poster publicized by the Botswanan NGO Elephants Without Borders (EWB) shows that the resettlement from Mudumu facilitated elephant mobility significantly. Elephants collared in Botswana today move in considerable numbers through Mudumu Park on their way north. Resettlement created a true wildlife corridor. While elephants otherwise stay on the Botswanan side of the Kwando River, they cross the Kwando into Mudumu National Park, and a number migrated through the state forest to Zambia from there (Lindsay et al. 2017: 265).

By the advent of Namibian independence, an environmental infrastructure had evolved on which further conservation projects could be built: clearly defined conservation areas, a riverine oasis emptied of human settlement, and villages lining

\footnotetext{
${ }^{43}$ See Lenggenhager (2018: 157); Lenggenhager published a copy of the original map, which is accessible at NAN CAF 6/19/5, 'Proposed nature reserves Caprivi'.

${ }^{44}$ Interview with indunas at Lizauli, 8 September 2018.
} 
the road at some distance from the river provided the necessary infrastructure for conservation planning in the 1990 s.

\section{Spatial organization under conservation in the twenty-first century}

After Namibian independence, the environmental infrastructure along the Kwando River further developed along conservationist lines. Following a change in conservation law in 1996 (Bollig and Menestrey Schwieger 2014; Silva and Mosimane 2014; Bollig and Olwage 2016), a number of community-based conservation projects were established along the Kwando River between 1999 and 2009. Seven conservancies (Kwando, Mayuni, Mashi, Balyerwa, Wuparo, Dzoti and Sobbe) were established along the eastern side of the Kwando River covering all the land from the Zambian border in the north to the Botswanan border in the south that did not belong to either Mudumu or Nkasa Rupara National Parks or to the state forest. In order to attain the privileges of a conservancy and to garner donor support, villages had to present themselves as a community, elect committees, and produce management plans and concise conservation plans detailing core conservation areas, wildlife corridors and zones earmarked for tourist investment (and not used for agriculture or livestock husbandry). Traditional authorities had to give their consent to the boundaries of conservancies before they were gazetted and to management plans and public-private partnerships. The linking of conservancy gazettement and procedures strengthened land governance through traditional authorities, formalized 'communities' and entrenched village territories (Silva and Mosimane 2014). Conservancies were able to market river frontage and rent out areas to tourism entrepreneurs - the habitation-free and also sleeping sickness-free wetlands in the valley being of prime interest from a tourism perspective. Today, there are fourteen tourism enterprises sited along the Kwando River overlooking the wetlands. ${ }^{45}$

In 2011, the Kwando landscape was integrated into the transnational KAZA conservation area, an area of more than 500,000 square kilometres that stretches across five Southern African countries. On the ground, inclusion within the KAZA conservation area did not change the way in which Namibian national parks and community-based conservation areas functioned. Potentially, however, their inclusion in the world's largest transboundary conservation area may lead to further conservationist environmental infrastructuring. Transnational wildlife migration corridors have been established, and transboundary forums between Namibian and Botswanan as well as Namibian and Zambian communities are meant to provide arrangements for such corridors. Figure 5 shows migration corridors running through the Zambezi region and providing 'migration highways' for wildlife. One key concern the conservancies are tasked with is to relocate people away from these migration corridors in an effort to provide for unhindered transboundary migrations of large ungulates. These relocations are not enforced but are the result of lengthy negotiations between conservancy leadership and local land users. Compensation claims are considered and alternative pastures are established through the drilling of additional boreholes.

\footnotetext{
${ }^{45}$ We thank L. Kalvelage, Department of Geography, University of Cologne, for the statistics on tourist infrastructure in the region.
} 


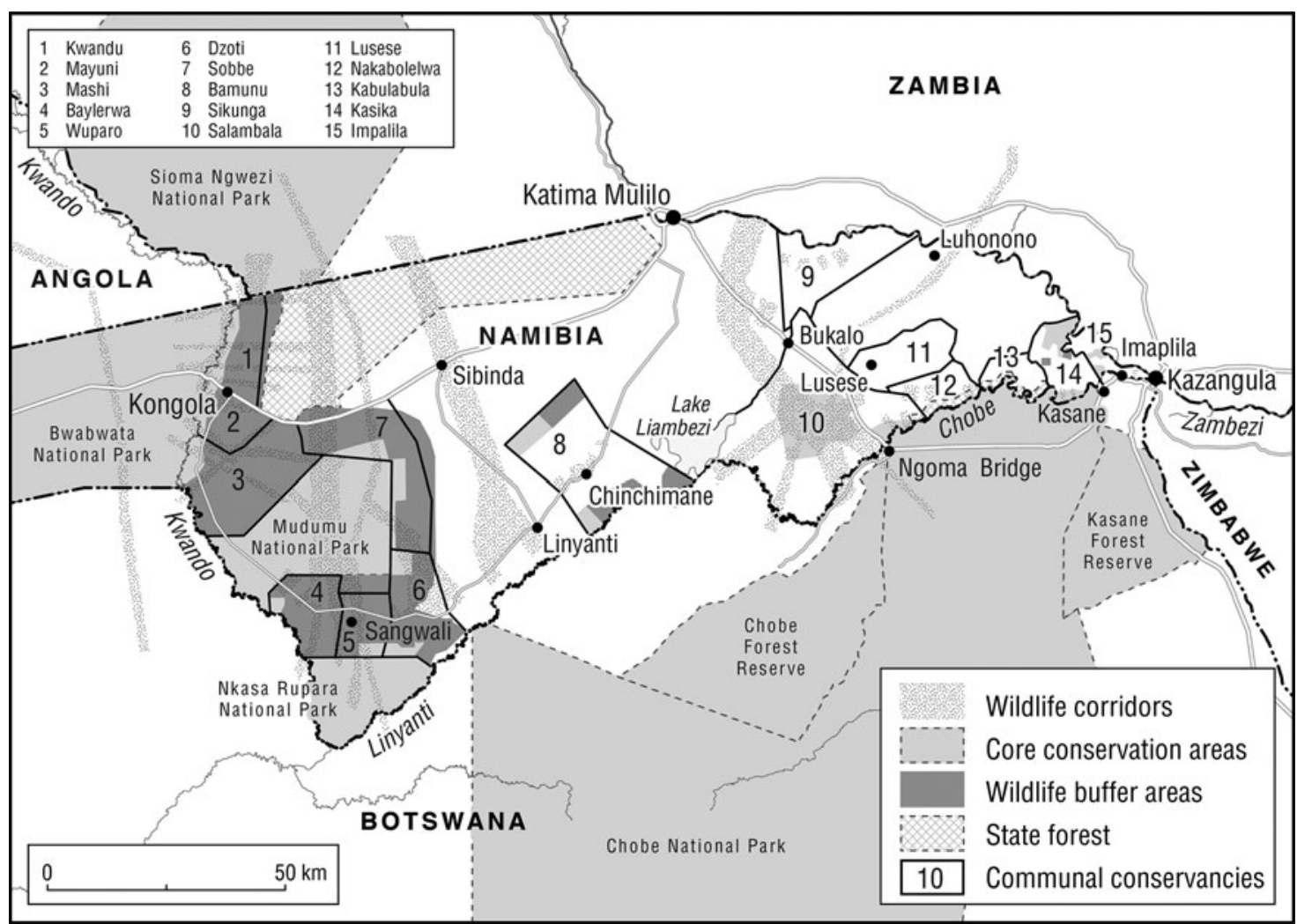

FIGURE 5 Namibia's Zambezi region, part of the KAZA transboundary park. The map shows conservation areas, conservancies, and wildlife migration corridors and tourist establishments (for the Kwando Valley only). 


\section{Conclusion}

The colonial government established an environmental infrastructure upon which today's conservation measures can and must build. It filled the eastern banks of the Kwando River with people and emptied its western banks and the extensive wetlands along the Kwando of inhabitants. It thereby coupled and decoupled actors, microbes, livestock and wildlife within this social-ecological system. Enforced and non-enforced relocations resulted in the termination of a lifestyle that had depended on the intensive linking of humans with the seasonality and volatility of the wetland landscape, and the interaction of humans with a myriad of other wetland species, from wildlife to flora, fish and insects. The reorganization of the landscape took some eight decades. Starting with relocations from Nkasa and Rupara islands in the early 1930s to the negotiations on resettlements in connection with the establishment of wildlife migration corridors in the 2010s, bio-cultural boundaries have shifted and land-use transformations have been prompted. At no stage were large groups of people relocated; the expulsion of around 300 people from Mudumu Park in 1980 was probably the most comprehensive resettlement measure. There was no masterplan for relocations; when the first was eventually drawn up in the 1960s - the Odendaal Plan - many relocations had already taken place. Earlier relocations originated in the administrative aspiration to isolate cattle herds, to combat the tsetse fly, to bring people closer to roads, and to make the population accessible for labour recruitment. On the Botswanan side of the river, the idea of prioritizing conservation over other development measures was dominant from the 1930s and became a fully fledged programme in the 1950s. From the 1960s, Namibia also saw a spate of large-scale development programmes, all of which were informed by the idea that zones of conservation had to be divided from zones of intensive use. These plans could build on the existence of emptied wetlands and of settlements along the major roads. The zoning of the landscape and the existence of unoccupied space in the wetlands but densely settled hinterlands created an optimal situation for the development of tourism from the 1980s onwards. Unoccupied space, abundant wildlife, scenic landscapes and the presence of labour made tourist investments lucrative. The zoning also created options for community-based natural resource management, formed communities, and embellished hybrid land-governance patterns combining local authority structures and global blueprints for sustainable communal resource management (Bollig and Menestrey Schwieger 2014). Emptied wetlands became typical core conservation areas of conservancies in the early 2000s, transboundary migration corridors in the 2010s, and zones that could be mapped as tourism sites, including lands that could eventually be rented out to lodges and campsites. Their inclusion within the KAZA conservation area creates new options for future transboundary tourist activities. The wetlands were not only emptied of human habitation but also of unwanted microbes and threatening weeds in order to produce an anthropogenic wilderness. If humanity wants to achieve the ambitious conservation goals set, for example, by the Nagoya Protocol and its Aichi targets, ${ }^{46}$ landscapes

\footnotetext{
${ }^{46}$ Many states worldwide, and most African states, signed the Nagoya Protocol of the UN Convention on Biological Diversity and its Aichi targets, which stipulate that 17 per cent of all terrestrial systems should be protected by 2020 .
} 
suitable for refaunation because of earlier separations of inhabited and noninhabited landscape, such as the Kwando River and its wetlands, will be of central importance. However, the creation of a conservation landscape does not come without costs. The relocation of people from the riverine areas and land-use changes and the transformation of smallholder livelihoods took place to enable the creation of an environmental infrastructure that allows many entrepreneurs to profit from tourism and hunting activities.

\section{References}

Bolaane, M. M. M. (2013) Chiefs, Hunters and San in the Creation of the Moremi Game Reserve, Okavango Delta: multiracial interactions and initiatives, 19561979. Senri Ethnological Studies 83. Suita, Osaka: National Museum of Ethnology.

Bollig, M. (2020) Shaping the African Savannah: from capitalist frontier to arid Eden in Namibia. Cambridge: Cambridge University Press.

Bollig, M. and D. A. Menestrey Schwieger (2014) 'Fragmentation, cooperation and power: institutional dynamics in natural resource governance in northwestern Namibia', Human Ecology 42 (2): 167-81.

Bollig, M. and E. Olwage (2016) 'The political ecology of hunting in Namibia's Kaokoveld: from Dorsland trekkers' elephant hunts to trophy-hunting in contemporary conservancies', Journal of Contemporary African Studies 34 (1): 61-79.

Breitenbach, F. von (1968) Long-term Plan of Forestry Development in the Eastern Caprivi Zipfel. Saasveld, South Africa: Department of Forestry <http://www. the-eis.com/data/literature/Von \%20Breitenbach $\% 201968 \% 20$ Long-term $\% 20$ Plan\%20Forestry\%20Dev\%20E\%20Caprivi.pdf>, accessed 23 May 2019.

Brockington, D. (2002) Fortress Conservation: the preservation of the Mkomazi Game Reserve, Tanzania. Oxford: James Currey and International African Institute.

Bundesbank (2019) Kaufkraftvergleiche historischer Geldbeträge. Frankfurt: German Federal Bank <https://www.bundesbank.de/de/statistiken/konjunkturund-preise/erzeuger-und-verbraucherpreise/kaufkraftvergleiche-historischer-geld betraege-775308\#tar-2>, accessed 16 December 2020.

Bundesbank (2020) Kaufkraftäquivalente historischer Beträge in deutschen Währungen. Frankfurt: German Federal Bank <https://www.bundesbank.de/ resource/blob/615162/3334800ed9b5dcc976da0e65034c4666/mL/kaufkraftae quivalente-historischer-betraege-in-deutschen-waehrungen-data.pdf $>$, accessed 16 December 2020.

Carruthers, J. (1995) The Kruger National Park: a social and political history. Pietermaritzburg: University of Natal Press.

Dieckmann, U. (2007) Hail|om in the Etosha Region: a history of colonial settlement, ethnicity and nature conservation. Basel: Basler Afrika Bibliographien.

Dressler, W., B. Büscher, M. Schoon, D. Brockington, T. Hayes, C. K. Kull, J. McCarthy and K. Shrestha (2010) 'From hope to crisis and back again? A critical history of the global CBNRM narrative', Environmental Conservation 37 (1): 5-15.

Fisch, M. (1996) Der Caprivizipfel während der deutschen Zeit 1890-1914. History, Cultural Traditions and Innovations in Southern Africa 2. Cologne: Rüdiger Köppe Verlag. 
Flint, L. S. (2003) 'State-building in Central Southern Africa: citizenship and subjectivity in Barotseland and Caprivi', International Journal of African Historical Studies 36 (2): 393-428.

Gumbo, G. B. (2010) 'Economic and social change in the communities of the wetlands of Chobe and Ngamiland, with special reference to the period since 1960'. $\mathrm{PhD}$ thesis, University of Cape Town <https://ibrary.wur.nl/ojs/index.php/ Botswana_documents/article/download/16000/15473>, accessed 13 February 2020.

Holub, E. (ed.) (1880) Sieben Jahre in Südafrika. Erlebnisse, Forschungen und Jagden auf meinen Reisen von den Diamantenfeldern zum Zambesi (18721879). Alte abenteuerliche Reiseberichte. Vienna: Hölder.

Kalvelage, L., J. Revilla Diez and M. Bollig (2020) 'How much remains? Local value capture from the tourism GPN in Zambezi, Namibia', Tourism Geographies.

Kangumu, B. (2011) Contesting Caprivi: a history of colonial isolation and regional nationalism in Namibia. Basel Namibia Studies Series 10. Basel: Basler Afrika Bibliographien.

Knight, C. G. (1971) 'The ecology of African sleeping sickness', Annals of the Association of American Geographers 61 (1): 23-44.

Kreike, E. (2013) Environmental Infrastructure in African History: examining the myth of natural resource management in Namibia. Cambridge: Cambridge University Press.

Kruger, C. E. (1984) 'History of the Caprivi Strip 1890-1984'. Unpublished manuscript, NAN A0472.

Kurugundla, C. N., P. M. Kgori and N. Moleele (2012) Management of Tsetse Fly Using Insecticides in Northern Botswana. London: IntechOpen <https://www. intechopen.com/citation-pdf-url/28274>.

Lenggenhager, L. (2018) Ruling Nature, Controlling People: nature conservation, development and war in north-eastern Namibia since the 1920s. Oxford: Basler Afrika Bibliographien.

Lindsay, K., M. Chase, K. Landen and K. Nowak (2017) 'The shared nature of Africa's elephants', Biological Conservation 215: 260-7.

Livingstone, D. (1870) Missionary Travels and Research in South Africa; including a sketch of sixteen years' residence in the interior of Africa, and a journey from the Cape of Good Hope to Loanda on the west coast; thence across the continent, down the River Zambezi, to the Eastern Ocean. New York NY: Harper \& Brothers.

Lubilo, R. and P. Hebinck (2019) “"Local hunting” and community-based natural resource management in Namibia: contestations and livelihoods', Geoforum 101: $62-75$.

Mavhunga, C. C. (2014) 'Seeing the national park from outside it: on an African epistemology of nature' in C. Mauch and L. Robin (eds), The Edges of Environmental History: honouring Jane Carruthers. Munich: RCC Perspectives.

Mendelsohn, J., A. Jarvis, C. Roberts and T. Robertson (2002) Atlas of Namibia: a portrait of the land and its people. Cape Town: David Philip <http://the-eis.com/ elibrary/search/8610>, accessed 15 December 2020.

MET and NACSO (2020) The State of Community Conservation in Namibia: annual report 2017. A review of communal conservancies, community forests and other CBNRM initiatives. Windhoek: Ministry of Environment and 
Tourism and Namibian Association of CBNRM Support Organisations < http:// www.nacso.org.na/sites/default/files/State $\% 20$ of $\% 20$ Community $\% 20$ Conservation \%20book\%20web_0.pdf>, accessed 13 February 2020.

Molefi, R. K. K. (2008) 'The impact of tsetse fly in Ngamiland, 1916-1955', Botswana Notes and Records 40: 35-45.

Morton, B. (1996) 'A social and economic history of a Southern African native reserve: Ngamiland 1890-1966'. PhD thesis, Indiana University.

Munang'andu, H. M., V. Siamudaala, M. Munyeme and K. S. Nalubamba (2012) 'A review of ecological factors associated with the epidemiology of wildlife trypanosomiasis in the Luangwa and Zambezi Valley ecosystems of Zambia', Interdisciplinary Perspectives on Infectious Diseases [online].

Phiri, B. J. (2005) 'Lozi kingdom and the Kololo' in K. Shillington (ed.), Encyclopedia of African History. Volume II: $\mathrm{H}-\mathrm{O}$. New York NY: Fitzroy Dearborn.

Potten, D. (1976a) 'Aspects of the recent history of Ngamiland', Botswana Notes and Records 8: 63-86.

Potten, D. (1976b) 'Etsha: a successful resettlement scheme', Botswana Notes and Records 8: 105-19.

Reid, P. C. (1901) 'Journeys in the Linyanti region', Geographical Journal 17 (6): 573-85.

Russell, E. (2001) War and Nature: fighting humans and insects with chemicals from World War I to Silent Spring. Studies in Environment and History. Cambridge: Cambridge University Press.

Schlettwein, C. and S. Bethune (1992) 'Aquatic weeds and their management in Southern Africa: biological control of Salvinia molesta in the Eastern Caprivi' in T. Matiza (ed.), Wetlands Conservation Conference for Southern Africa: proceedings of the Southern African Development Coordination Conference, held in Gaborone, Botswana, 3-5 June 1991. Gland: International Union for Conservation of Nature (IUCN).

Schlettwein, C. and J. H. Giliomee (1990) 'The effects of different dosages of the insecticide mixtures endosulfan/alphamethrin on adults of the biological control agent Cyrtobagous salviniae (Coleoptera: Curculionidae) against Salvinia molesta', Madoqua 17 (1): 37-9.

Seiner, F. (1909a) Die wirtschaftsgeographischen und politischen Verhältnisse des Caprivizipfels. Berlin: Wilhelm Süsserott.

Seiner, F. (1909b) Ergebnisse einer Bereisung des Gebietes zwischen Okavango und Sambesi (Caprivi-Zipfel) in den Jahren 1905 und 1906: Mitteilungen aus den Deutschen Schutzgebieten. Volume 22. Berlin: Ernst Siegfried Mittler und Sohn.

Selous, F. C. (1881) A Hunter's Wanderings in Africa: being a narrative of nine years spent amongst the game of the far interior of South Africa. London: Rowland Ward and Co.

Silva, J. A. and A. Mosimane (2014) "How could I live here and not be a member?": Economic versus social drivers of participation in Namibian conservation programs', Human Ecology 42 (2): 183-97.

Skarpe, C., H. Hytteborn, S. R. Moe and P. A. Aarrestad (2014a) 'Historical changes of vegetation in the Chobe area' in C. Skarpe, J. T. Du Toit and S. R. Moe (eds), Elephants and Savanna Woodland Ecosystems: a study from Chobe National Park, Botswana. Chichester and Hoboken NJ: John Wiley and Sons. 
Skarpe, C., S. R. Moe, M. Wallgren and S. Stokke (2014b) 'Elephants and the grazing and browsing guilds' in C. Skarpe, J. T. Du Toit and S. R. Moe (eds), Elephants and Savanna Woodland Ecosystems: a study from Chobe National Park, Botswana. Chichester and Hoboken NJ: John Wiley and Sons.

Spinage, C. (2012) African Ecology: benchmarks and historical perspectives. Berlin: Springer.

Streitwolf, H. (1911) Der Caprivizipfel. Berlin: Süsserott.

Taylor, J. J. and W. Beinart (2012) Naming the Land: San identity and community conservation in Namibia's West Caprivi. Basel Namibia Studies Series 12. Basel: Basler Afrika Bibliographien.

Tlou, T. (1985) A History of Ngamiland, 1750 to 1906: the formation of an African state. Gaborone: Macmillan Botswana.

van der Vegte, J. H., C. W. Foster and W. B. Forse (1983) Eastern Caprivi Regional Development Strategy. Windhoek: Directorate of Development Co-ordination and Statistics.

Vandewalle, M. E. and K. A. Alexander (2014) 'Guns, ivory and disease: past influences on the present status of Botswana's elephants and their habitats' in C. Skarpe, J. T. Du Toit and S. R. Moe (eds), Elephants and Savanna Woodland Ecosystems: a study from Chobe National Park, Botswana. Chichester and Hoboken NJ: John Wiley and Sons.

Wallace, M. and J. Kinahan (2013) A History of Namibia: from the beginning to 1990. Oxford: Oxford University Press.

Zeller, W. (2010) 'Neither arbitrary nor artificial: chiefs and the making of the Namibia-Zambia borderland', Journal of Borderlands Studies 25 (2): 6-21.

\begin{abstract}
The Kwando Basin of north-eastern Namibia is firmly embedded in current national and international conservation agendas. It is a key part of the world's largest transboundary conservation area, the Kavango-Zambezi (KAZA) Transfrontier Conservation Area, and the home of seven community-based conservation areas (conservancies) and three smaller national parks (Mudumu, Nkasa Rupara and Bwabwata). While conservation agendas often start from the assumption that an authentic part of African nature is conserved as an assemblage of biota that has not been gravely impacted by subsistence agriculture, colonialism and global value chains, we show that environmental infrastructure along the Namibian side of the Kwando Valley has been shaped by the impact of administrative measures and the gradual decoupling of humans and wildlife in a vast wetland. The way towards today's conservation landscape was marked and marred by the enforced reordering of human-environment relations; clearing the riverine core wetlands of human habitation and concentrating communities in narrowly defined settlement zones; the suppression of specific, wetland-adapted subsistence practices; and the elimination of unwanted microbes with the help of insecticides. The interventions in the ecosystem and the construction of an environmental infrastructure have created a unique conservation landscape in the Namibian Zambezi region, which provides the foundation for its popularity and success.
\end{abstract}




\section{Résumé}

Le bassin fluvial du Kwando, dans le nord-est de la Namibie, est fermement intégré dans des programmes actuels nationaux et internationaux de protection de la nature. C'est un élément clé de la plus grande zone de protection transfrontalière au monde, nommée Kavango-Zambezi Transfrontier Conservation Area (KAZA), qui abrite sept zones de protection (réserves communautaires) et trois parcs nationaux de taille modeste (Mudumu, Nkasa Rupara et Bwabwata). Alors que les programmes de protection partent souvent de l'hypothèse qu'une partie authentique de la nature africaine est protégée sous la forme d'un assemblage de biotes qui n'a pas été gravement impacté par l'agriculture de subsistance, le colonialisme et les chaînes de valeur mondiales, les auteurs montrent que l'infrastructure environnementale le long de la partie namibienne de la vallée du Kwando a été façonnée par l'impact de mesures administratives et le découplage progressif entre l'humain et la faune sauvage sur de vastes zones humides. La voie qui a conduit au paysage de protection actuel a été marquée et entachée par le réordonnancement forcé des relations entre l'humain et l'environnement; le retrait des habitations humaines des zones humides centrales fluviales et la concentration des communautés dans des zones de peuplement étroitement définies; la suppression de pratiques spécifiques de subsistance adaptées aux zones humides; et l'élimination de microbes indésirables à l'aide d'insecticides. Les interventions dans l'écosystème et la construction d'une infrastructure environnementale ont créé dans la région du Zambèze en Namibie un paysage de protection unique qui fournit les bases de sa popularité et de son succès. 